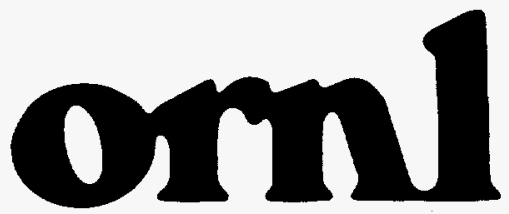

OAK RIDGE

NATIONAL

LABORATORY

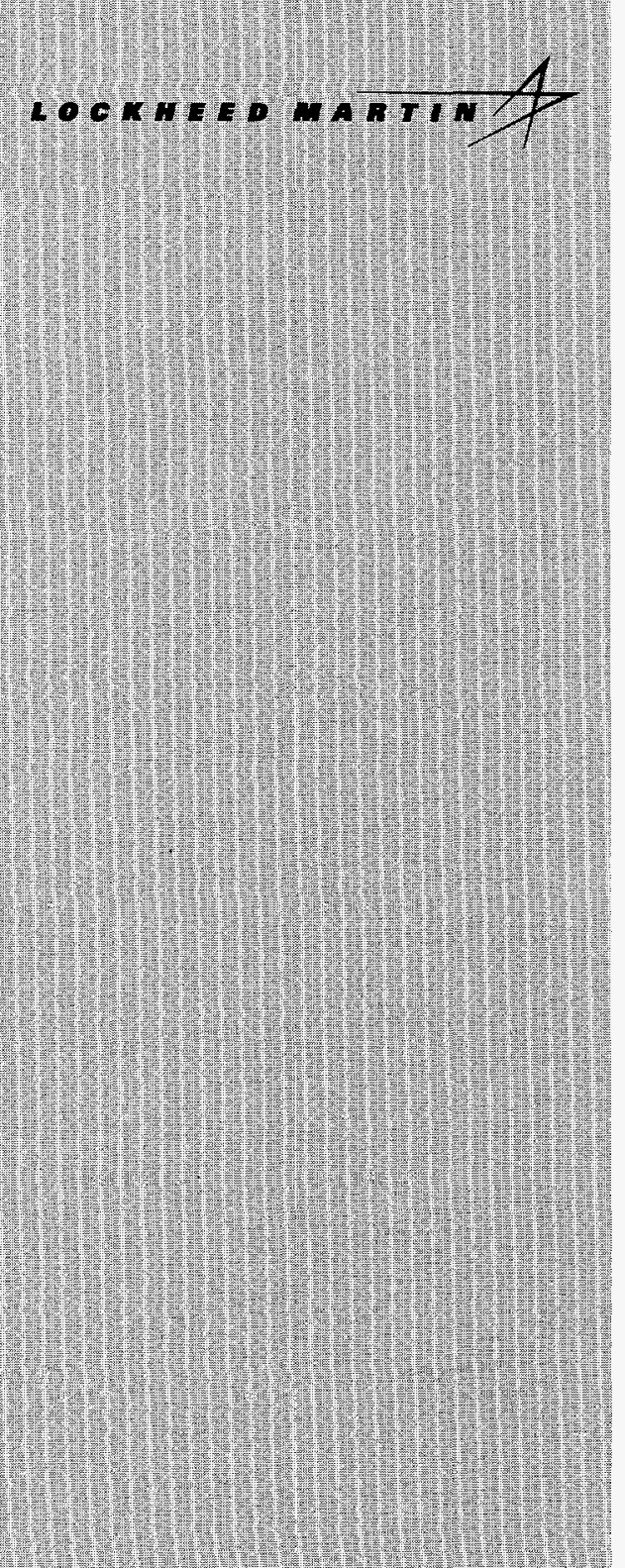

WANAGED AWD OPERATED BY

LOCKHEED WARTW ENERGY RESEARCH CORPORATION FOA THE ULTED STATES

DEPARTIENT OF ENERGY
RECEIVED

$$
\begin{array}{r}
\text { FFR } 17 \text { 1998 } \\
\text { OSTI }
\end{array}
$$

\title{
Technical Support Section Annual Work Plan for FY 1998
}

\author{
B. P. Adkisson \\ K. L. Allison \\ R. P. Effler \\ R. A. Hess \\ T. A. Keeble \\ S. M. Odom \\ D. R. Smelcer
}
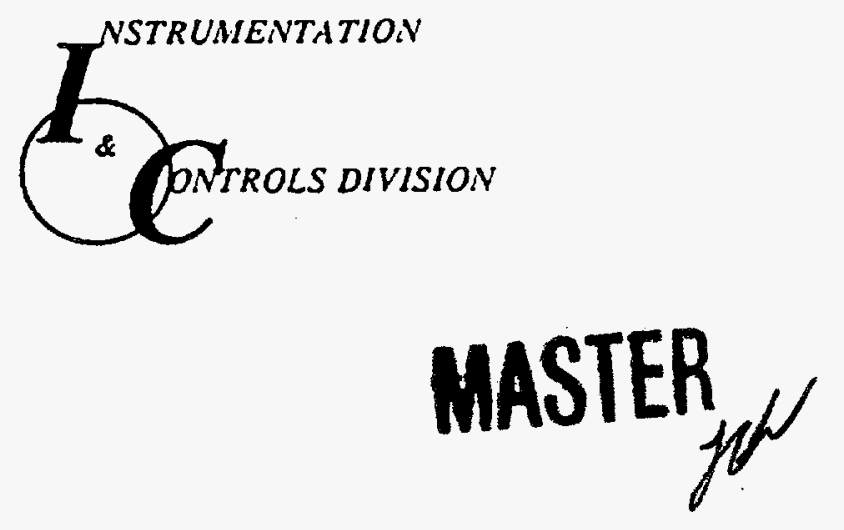

DISTRIBUTION OF THIS DOCUMENT SS LAIIITED 
This report has been reproduced directly from the best available copy.

Available to DOE and DOE contractors from the Office of Scientific and Technical Information, P.O. Box 62, Oak Ridge, TN 37831; prices available from (423) 576-8401, FTS 626-8401.

This report was prepared as an account of work sponsored by an agency of the United States Government. Neither the United States Government nor any agency thereof, nor any of their employees, makes any warranty, express or implied, or assumes any legal liability or responsibility for the accuracy, completeness, or usefulness of any information, apparatus, product, or process disclosed, or represents that its use would not infringe privately owned rights. Reference herein to any specitic commercial product, process, or service by trade name, trademark, manufacturer, or otherwise, does not necessarily constitute or imply its endorsement, recommendation, or favoring by the United States Government or any agency thereof. The views and opinions of authors expressed herein do not necessarily state or reflect those of the United States Government or any agency thereot. 


\section{DISCLAIMER}

Portions of this document may be illegible electronic image products. Images are produced from the best available original document. 
Instrumentation and Controls Division

\title{
TECHNICAL SUPPORT SECTION ANNUAL
} WORK PLAN FOR FY 1998
B. P. Adkisson
K. L. Allison
R. P. Effler
R. A. Hess
T. A. Keeble
S. M. Odom
D. R. Smelcer

Date Published: December 1997

\author{
Prepared by \\ OAK RIDGE NATIONAL LABORATORY \\ Oak Ridge, Tennessee 37821-6285 \\ managed by \\ LOCKHEED MARTIN ENERGY RESEARCH CORP. \\ for the \\ U.S. DEPARTMENT OF ENERGY \\ under contract DE-AC05-96OR22464
}




\section{CONTENTS}

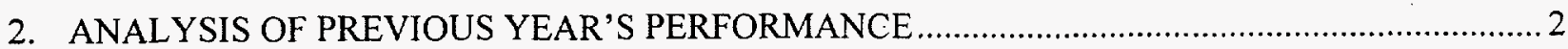

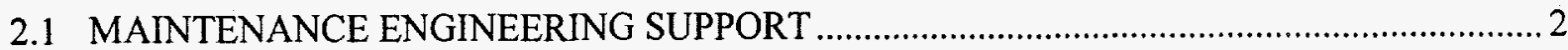

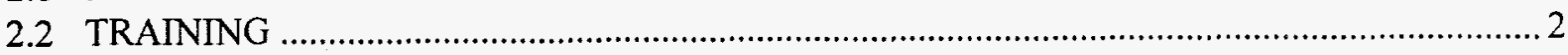

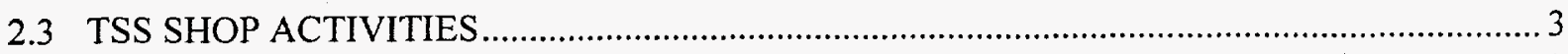

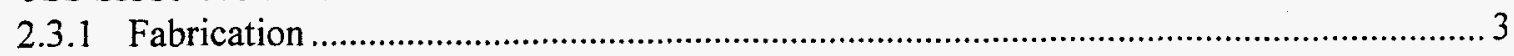

2.3.2 Thermal Testing for the Metals and Ceramics Division ............................................. 3

2.3.3 Filter Ventilation System at the North Tank Farm ................................................. 3

2.3.4 Building 6000 Control Panel Upgrade ....................................................................... 3

2.3.5 Upgrade of Stationary Alpha and Beta-Gamma Personnel Radiation Monitors................ 4

2.3.6 Radio Console Replacement................................................................................. 4

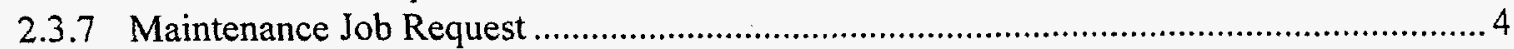

2.3.8 Badge Readers Used to Collect Training Information ................................................. 4

2.3.9 Technical Assistance Hotline-Electrical Calibration................................................. 4

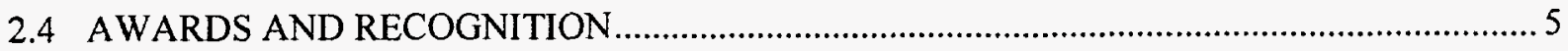

2.4.1 Tennessee Quality Commitment Award...................................................................... 5

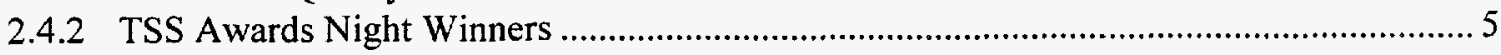

2.4.3 New Manager of the Year Award................................................................................... 5

2.4.4 Significant Event Award Winners .............................................................................. 6

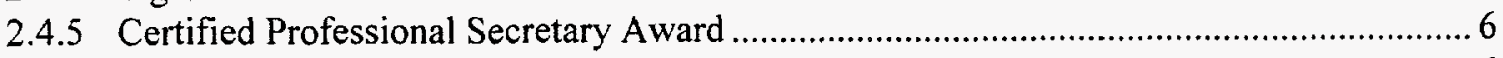

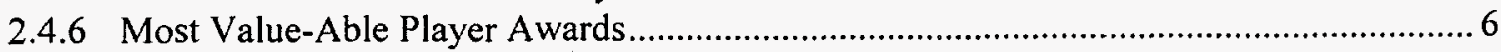

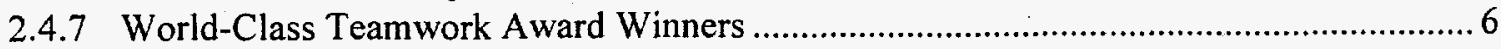

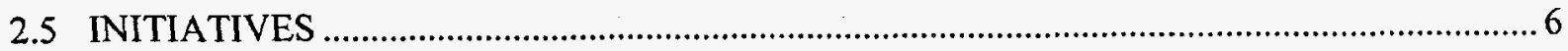

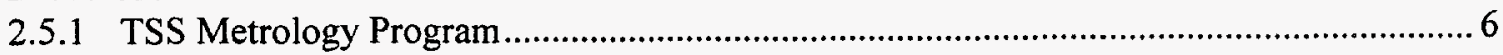

2.5.2 Make-Buy (Outsourcing) Committees Formed .............................................................. 7

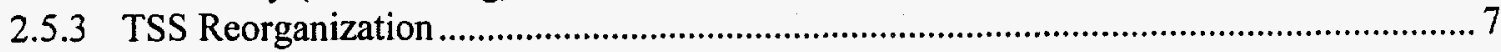

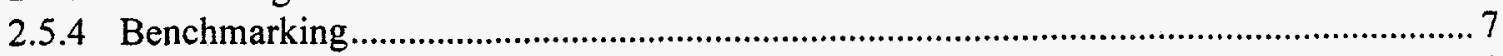

2.6 LEADERSHIP DEVELOPMENT FOR FIRST-LINE SUPERVISORS ............................... 8

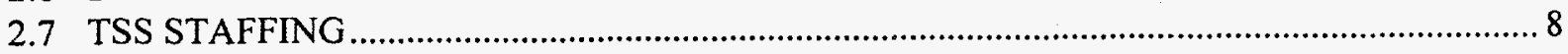

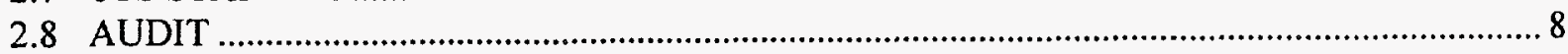

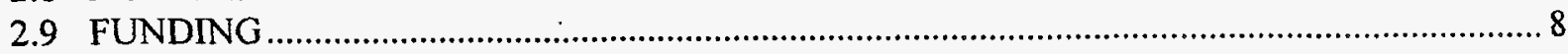

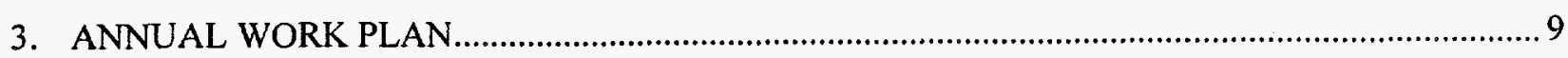

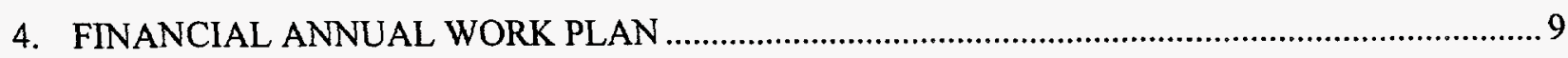

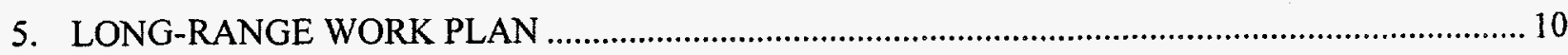




\section{INTRODUCTION AND OVERVIEW}

The Technical Support Section (TSS) of the Instrumentation and Controls (I\&C) Division of Oak Ridge National Laboratory (ORNL) provides technical services such as fabrication, modification, installation, calibration, operation, repair, and preventive maintenance of instruments and other related equipment. It is the mission of TSS to support programs and policies of ORNL, emphasizing safety and ensuring cost-effective support for research and development (R\&D). Work performed by TSS supports basic and applied $R \& D$, engineering, and instrument and computer systems managed by ORNL.

Because the activities and priorities of TSS must be adapted to the technical support needs of ORNL, the TSS Annual Work Plan is derived from, and is driven directly by, current trends in the budgets and activities of each ORNL division for which TSS provides support. Trends that will affect TSS planning during this period are reductions in the staffing levels of some R\&D programs because of attrition or budget cuts.

TSS does not have an annual budget to cover operating expenses incurred in providing instrument maintenance support to ORNL. Each year, TSS collects information concerning the projected funding levels of programs and facilities it supports. TSS workforce and resource projections are based on the information obtained and are weighted depending on the percentage of support provided to that division or program. Each year, TSS sets the standard hourly charge rate for the following fiscal year. The standard rate is based on the projected annual inflation rate, proposed increases or decreases in staffing because of perceived changes in program or division funding, upgrade of aging equipment or facilities, overhead burden, compliance with new requirements or directives, labor contract negotiations, and the fringe-benefit rate. The standard rate is charged to customer accounts or work orders as the work is performed. A cost variance occurs when there is a difference between the actual cost per hour and the standard rate per hour. Typically, this variance is positive during months of high fringe-benefit cost (holidays and vacation) or when materials or equipment are costed by Accounts Payable. Variances are negative during months with minimal fringe-benefit cost and when materials purchased for maintenance support are charged back to customer accounts.

The Long-Range Work Plan (see Sect. 5) is based on estimates of the affects of the long-range priorities and directions of the Laboratory. Proposed new facilities and programs provide additional bases for long-range planning. After identifying long-range initiatives, TSS planning includes future training requirements, reevaluation of qualifications for new hires, and identification of essential test equipment that will be needed for new work.

Although TSS has no direct responsibility for the maintenance or repair of real property, it does perform breakdown maintenance, preventive maintenance, and calibration of Laboratory production and experimental equipment, all of which is used for programmatic purposes. Operating expense funds from supported divisions support this type of equipment. 


\section{ANALYSIS OF PREVIOUS YEAR'S PERFORMANCE}

\subsection{MAINTENANCE ENGINEERING SUPPORT}

TSS maintenance engineers/planners contributed substantially to several projects for ORNL research divisions and for Laboratory support. Among these were the following:

- The Atlanta Advanced Driver Adviser System program.

- The Gunite Acceptance and Accountability Test tank mapping system.

- The Parking and Routing Information System project.

- The ORNL Data Acquisition System for Crash Avoidance Research (DASCAR) project.

- The Australia DASCAR project.

- The Association between Speed and Crash Probabilities project.

\subsection{TRAINING}

Current I\&C/TSS Baseline Evaluation Testing and Training programs approved by the U.S. Department of Energy (DOE) are the result of previous evaluations by DOE against compliance orders and directives. To ensure compliance, programmatic training was conducted, documented, and tracked with in-house database management and tracking systems. Personnel requiring proof of initial and continuing training to perform work in nonreactor nuclear facilities were initially qualified with "qual" cards signed by their supervisors, providing evidence of initial qualification. Evidence of continuing training is tracked using a database-generated training status report. To standardize record keeping, hardcopy documentation is systematically filed in personnel training folders. Current or updated environmental, safety, and health; facility-specific; and job-specific checklists provide a matrix to customize the individual training needs of TSS employees based on the type of work performed and provide a method to continuously review and update training needs.

Employees also receive core subject training for unescorted access to nuclear facilities based on customer requests and the needs of work assignments. ORNL training providers maintain current modules and lesson plans to ensure that employees remain current with changing compliance documents, procedures, and directives. This allows TSS to use cost-effective training to the fullest extent by reallocating resources for employee career development. On-site technical training provides savings by maximizing the time spent in a training environment with minimum time spent off the job.

Structured on-the-job training is the preferred method for performance-based instruction within TSS. Subject matter experts are responsible for training and documenting job-related qualifications for technicians by drafting, validating, and ensuring correct performance of TSS technical procedures. In FY 1997, 141 TSS personnel completed 1404 training events, an average of 10 events per person. TSS front-line supervisors have real-time data available to provide current assessments of personnel to effectively manage resources. 


\subsection{TSS SHOP ACTIVITIES}

\subsubsection{Fabrication}

The I\&C Fabrication program had dwindled to a small operation by October 1996. Aggressive marketing investigations resulted in a plan for "turning the program around." The first major project toward this end was to fabricate 50 printed circuit board assemblies for the highly enriched uranium/low-enriched uranium (HEU/LEU) blend-down project. The HEU blend-down project is a high-profile endeavor in which ORNL is making a significant contribution to the reduction of the world's nuclear arms stockpile. The work had already been outsourced, but we were able to convince the program managers to allow the I\&C Fabrication group to perform the work, even though it represented a "critical path" to a strict deadline. The work was finished in an exemplary fashion, and several field modifications were made that would not have been possible had the job been outsourced. Our success with the HEU/LEU blend-down project opened up what had previously been a largely untapped source of sponsorship. We now have two fully equipped and qualified "Surface Mount Technology" (SMT) installation and repair technicians who are employed full-time in this state-of-the-art fabrication technique. Because of the favorable response, we anticipate needing several more SMT technicians.

\subsubsection{Thermal Testing for the Metals and Ceramics Division}

A TSS technician and two Plant and Equipment (P\&E) Division crafts workers set up a thermal fatigue cycling test system for the Metals and Ceramics Division. The apparatus can be used to simulate the alternate heating and cooling in dies or components for a variety of processes including casting, forging, and heat treating. The programmable controller is a Research Incorporated Micristar used to control an induction heater and two solenoid valves. The process cycles automatically for a preset number of times without human control. The work is being supported by the Advanced Industrial Materials Program, Office of Industrial Technology, Lightweight Vehicle Materials program, Office of Transportation Technology, Energy Efficiency and Renewable Energy, and DOE.

\subsubsection{Filter Ventilation System at the North Tank Farm}

Instrument technicians in the Process Industrial Instrumentation Shop completed the high-efficiency particulate air filter ventilation system for the north tank farm. This was a joint project involving TSS, I\&C Engineering, the Office of Environmental Compliance and Documentation, P\&E, and the Waste Management and Remedial Action Division. The system was designed by TSS and I\&C Engineering to provide off-gas ventilation for the tanks during the sluicing experiment. The filter control design was prepared by I\&C Engineering and was built and installed by TSS instrument technicians. TSS designed, fabricated, and installed the National Emission Standards for Hazardous Air Pollutants sampling system. After the system was installed, Health Physics had a concern regarding loss of ventilation caused by a complete power loss. A self-charging battery backup alarm system was designed that will provide a flashing amber light for approximately 15 minutes if a total power failure occurs.

\subsubsection{Building 6000 Control Panel Upgrade}

Indicator lights were burning out on control panels and power supplies, creating operator problems. An 
instrument technician researched the type-387 incandescent bulbs that were being used and found that the life cycle was approximately three months. A light-emitting diode (LED)-type bulb with an average life span of 100,000 hours was used as a replacement for the former bulb. The result of the replacement bulb was so successful that all bulbs were replaced in the indicating devices in the building. This effort resulted in savings of time, money, and material. The reliability and integrity of the equipment were also improved.

\subsubsection{Upgrade of Stationary Alpha and Beta-Gamma Personal Radiation Monitors}

TSS was tasked with replacing ORNL-designed radiation monitors with new Bicron Surveyor MX units that are being modified for stationary use. The old monitors will be sent to property sales as surplus equipment. All ORNL-manufactured monitors are scheduled for replacement by the end of calendar year 1997. The new Bicron units require one hour to calibrate. The old ORNL monitors took from two to four hours if repairs were needed. This is a minimum cost savings of $50 \%$ in work hours. Since the upgrade began, TSS has exchanged 105 monitors; 86 old monitors remain to be replaced.

\subsubsection{Radio Console Replacement}

The Communication and Security Shop completed the radio console upgrade project in the shift supervisor's office. New consoles were also installed in the Security Department. These upgrades will improve the quality and reliability of these vital dispatch centers. These installations were completed during a weekend, which kept the disruption of service to the Laboratory at a minimum. Communication and Security Shop technicians located and procured the console equipment from surplus equipment located at the Y-12 Plant. Use of this surplus equipment resulted in a cost saving of approximately $\$ 50,000$ to the Security Department.

\subsubsection{Maintenance Job Request}

TSS designed a Web-based Maintenance Job Request (MJR) to be used by customers, technicians, and data-entry personnel. This program reduces the work required for customers and TSS personnel to enter a work request. The data entry person is no longer required to log into e-mail, print a work request from the customer, and reenter information into the TSS data system. The Web MJR data are downloaded to the TSS system each hour. The data-entry person logs into the TSS information database and accepts and assigns the work request to a technician in a single step.

\subsubsection{Badge Readers Used To Collect Training Information}

TSS used programs built to interface with the Intermec badge readers to collect information necessary for the Training Management System (TMS) database records. The badge readers are used for all training and safety meetings conducted in the I\&C Division. All attendance information collected was downloaded to TMS with no errors. The I\&C Division saved $\$ 1600$ during the division ethics training conducted in June by using badge readers in lieu of TMS to collect attendance information.

\subsubsection{Technical Assistance Hotline-Electrical Calibration}

TSS responded to a DOE technical assistance request from Adroit Medical Machine Co. for help in measuring the electrical leakage, noise level, and fluid velocity of a pump immersed in a fluid. The tests were performed by TSS instrument technicians assisted by $1 \& C$ metrology engineers, who certified the results. A copy of the resulting technical report was sent to the technical assistance office. 
The task required the solution of several difficult measurement problems and, therefore, required considerable study and expertise. This work is an excellent example of how a national laboratory can be a valuable resource to the private sector, particularly to smaller high-tech companies that do not have internal resources to solve such problems. As a result of their efforts, the TSS technicians received a World-Class Teamwork Award.

\subsection{AWARDS AND RECOGNITION}

\subsubsection{Tennessee Quality Commitment Award}

The Tennessee Quality Commitment Award was presented to TSS at the annual awards dinner on October 24, 1996, at the Nashville Renaissance Hotel. Over 1000 people representing participating Tennessee companies, organizations, and support groups statewide attended the ceremony.

Winners of the Level 2 Quality Commitment Award have advanced from quality knowledge and skills to a point of serious commitment, with participants being recognized for specific accomplishments. This is the intermediate level for organizations that have advanced from their initial steps toward total quality improvement and are recognized for their accomplishments toward the next level of achievement. To reach Level 2, everyone contributes his or her strengths and communicates very effectively toward a focused target of quality in every action.

Tennessee Governor Sundquist said "The quest for quality distinguishes our state as a place where innovators flourish, consistently high standards are set, and a highly trained competent workforce is on-line for the future."

Marie B. Williams, director of the Tennessee Quality Awards program, said "We have highly motivated, committed people working to improve quality and productivity in businesses and industries throughout Tennessee. Quality is an ongoing journey, and we are proud of the efforts the Lockheed Martin Energy Research Corporation, the Instrumentation and Controls Division, the Technical Support Section, and many other organizations in our state have made in this area."

\subsubsection{Awards Night Winners}

Three TSS bargaining unit employees received recognition at the annual Lockheed Martin Energy Research Awards Night:

- John Bui for using his personal initiative to make himself an integral part of a research team instead of merely a service provider.

- Peggy DePorter for providing service so excellent that it made her an indispensable part of a team that accomplished a major national security breakthrough.

- Frank Rau for bringing a virtually unprecedented degree of professionalism to a craft position.

\subsubsection{New Manager of the Year Award}

Gary Inman, supervisor of the Communication and Security Group, was selected by the National Management Association as the 1997 New Manager of the Year. 


\subsubsection{Significant Event Award Winners}

Billy Staggs and Woody Bledsoe received a Significant Event Award for the design, installation, and testing of a threaded mounting in a new pH adjustment system in Building 2099. This corrected a personnel hazard and an as-low-as-reasonably-achievable issue.

Faye Jackson and Carolyn Rayder received a Significant Event Award for the administrative support of the P\&E Research Support Services Process Reengineering Effort.

\subsubsection{Certified Professional Secretary Award}

Faye Jackson received her Certified Professional Secretary (CPS) rating after successfully passing the CPS national examination in May 1997.

\subsubsection{Most Value-Able Player Awards}

Nominations for these awards are made by fellow employees and are based on the observation of values in the day-to-day work operation. Award recipients were instrument technicians Joey Weaver, David Thomas, and Frank Rau and TSS section secretary Carolyn Rayder.

\subsubsection{World-Class Teamwork Award Winners}

Recipients of World-Class Teamwork Awards were Tim McKnight, Jim Hylton, Greg Strickland, and Jon Auer.

\subsection{INITIATIVES}

\subsubsection{TSS Metrology Program}

The I\&C Division's Metrology Research and Development Laboratory (MRDL) was recently placed under the administrative oversight of TSS. Subsequently, the Electrical and Physical Calibration programs were subsumed by Metrology, and the composite program was assigned to a single manager. The purpose of this reorganization was to enhance the efficiency of TSS calibration operations, which had always depended heavily on MRDL for traceability of standards. This will allow the sharing of staff and equipment and eliminate a significant amount of duplicated effort. The two calibration laboratories were physically relocated to Building 3500, in the MRDL facility.

An effort is under way to improve the funding base of the Metrology/Calibration program by requesting that fixed infrastructure costs be recovered from ORNL overhead rather than be included in the program's charge-out rate. It is believed that the Metrology/Calibration Lab's infrastructure benefits all ORNL programs either directly or indirectly since both publishers of research data and managers of facilities rely on TSS Metrology/Calibration to establish the traceability of research and safety/compliance instrumentation calibration. 


\subsubsection{Make-Buy (Outsourcing) Committees Formed}

TSS presented the services it provides to the ORNL Make-Buy Steering Committee for review as possible outsource candidates. The committee determined that field calibrations, fabrication, R\&D support, and operational support clearly needed to be accomplished by in-house staff and would not be considered for outsourcing. Calibration services and automatic data processing equipment (ADPE) systems maintenance were chosen by the Steering Committee for further evaluation. Based on the decision of the Steering Committee, two separate teams were formed to examine and study in detail these services and outside vendors that provide like services. The objective was to identify a detailed description of the service provided and solicit the cost for this service from vendors. The teams were composed of cross-functional groups with representatives from the Office of Safety and Health Protection, Procurement, TSS, Finance, and the Atomic Trades and Labor Council.

The decision to continue providing calibration services internally was reached rapidly. This decision was based on the unique service performed by TSS that was identified during development of the statement describing the type of work performed. Regarding ADPE systems maintenance, the team developed a statement describing services offered by TSS, collected comparison cost data from vendors, and analyzed these data. This proved to be a time-consuming process that continued over an eight-month period. Based on this analysis, the team recommended continuing this service internally, which was accepted by the Steering Committee.

\subsubsection{TSS Reorganization}

Consolidation of the Personal Computers and the Network and Systems Support shops enabled TSS to eliminate two first-line supervisor positions. Personnel in the self-managed group were reassigned to shops located close to their area of work. With this reorganization, TSS consolidated eight customer service shops into six, with emphasis on serving the customer more cost efficiently.

\subsubsection{Benchmarking}

TSS has continued its benchmarking efforts since the previous report. As part of the make-buy analysis efforts, TSS collected information from various agencies regarding calibration services and ADPE systems. This information was useful to those analyses as well as to TSS. The information collected is being used to assist TSS in determining possible improvements to the organization. One conclusion reached was that there is no one clearly defined way of providing some of the services that TSS provides. What proved to be successful at some locations was the opposite of what proved successful at other sites. 


\subsection{LEADERSHIP DEVELOPMENT FOR FIRST-LINE SUPERVISORS}

All TSS supervisors participated in a training exercise designed by the Tom Peters Group that focuses on five leadership practices:

- Challenging the Process

- Inspiring a Shared Vision

- Enabling Others to Act

- Modeling the Way

- Encouraging the Heart

Throughout the training, participants apply innovative thinking and team-building techniques to make complex decisions.

\subsection{TSS STAFFING}

As a result of transfers and retirements, TSS lost ten staff members during this reporting period. The change in staff resulted from the retirement of two first-line supervisors, two instrument technicians, and a staff engineer. The other changes in TSS staffing resulted from the transfer of a staff engineer to the I\&C Engineering Section and from four instrument technicians accepting positions with other firms.

Current staffing levels are expected to remain relatively constant during FY 1998 as we continue to streamline our operations and reduce operating costs.

\subsection{AUDIT}

TSS participated in one major audit this reporting period. The Energy Systems Evaluation Group conducted an assessment of ORNL's nonreactor nuclear facilities on April 14-25, 1997. Nine facilities were included in the assessment, which focused on the level of compliance with the facility authorization basis documentation and the implementation of Conduct of Operations principles. As a part of this activity, reviews were conducted of I\&C-maintained records of tests and calibrations related to Operational Safety Requirements and Limiting Conditions Documents. After the assessment was completed, a root cause analysis team was formed to evaluate the violations identified in the assessment and to formulate a corrective action plan to resolve the deficiencies. This audit was composed of an overview briefing, document reviews, staff interviews, a facility walkthrough, and field observations.

\subsection{FUNDING}

The total TSS budget for FY 1997 was $\$ 9,070,842$, which does not include any overhead funding. This represents an overall charge-out rate of $\$ 46.50$ /hour for the more than 201,110 hours of service provided by TSS and is $\$ 38,042$ less than the original projected cost at the beginning of the year. This reduced rate was achieved by analyzing components in the TSS budget, devising ways to reduce spending, increasing productivity, and reducing the overall number of supervisors. The savings 
associated with staff reductions will be recognized for all future years. The major components of the TSS rate include payroll and fringe (77.9\%), materials (4.4\%), and support services $(17.7 \%)$.

The FY-1998 rate has been set at $\$ 49.15 /$ hour. Components driving the increase include inflation and investments TSS is making in the staff through additional training. Additionally, TSS continues to analyze the budget and promote more cost-efficient ways to conduct business.

\section{ANNUAL WORK PLAN}

Each major research division was contacted to determine the projected programmatic level of funding for the next fiscal year. Most divisions projected that their funding levels would remain near those of FY 1997 or slightly decrease. Overall, FY-1998 operating-expense-funded maintenance and repair requirements for ORNL are projected to be relatively level with those of FY 1997. Analysis was performed of DOE orders and technical training needs to evaluate training program costs, work force requirements, and types of qualifications for new hires. Routine and breakdown maintenance is expected to remain relatively stable, enabling work to be performed by current staffing levels.

\section{FINANCIAL ANNUAL WORK PLAN}

\begin{tabular}{|c|c|c|c|c|c|c|c|c|}
\hline \multirow{2}{*}{ Maintenance } & \multicolumn{2}{|c|}{ FY 1997} & \multicolumn{2}{|c|}{ FY 1998} & \multicolumn{2}{|c|}{ FY 1999} & \multicolumn{2}{|c|}{ FY 2000} \\
\hline & Budget & FTEs & Budget & FTEs & Budget & FTEs & Budget & FTEs \\
\hline Administration & 658 & 9 & 706 & 9 & 727 & 9 & 748 & 9 \\
\hline Calibration \& Testing & 585 & 8 & 846 & 8 & 871 & 8 & 897 & 8 \\
\hline $\begin{array}{l}\text { Communications \& } \\
\text { Security }\end{array}$ & 1,170 & 16 & 1,243 & 16 & 1,280 & 16 & 1,319 & 16 \\
\hline Electronic Instrumentation & 1,170 & 16 & 1,236 & 16 & 1,273 & 16 & 1,312 & 16 \\
\hline Fabrication \& Metalphoto & 951 & 13 & 1,004 & 13 & 1,034 & 13 & 1,065 & 13 \\
\hline Facility Support & 1,170 & 16 & 1,240 & 16 & 1,277 & 16 & 1,315 & 16 \\
\hline $\begin{array}{l}\text { Personal Computers \& } \\
\text { Networking }\end{array}$ & 2,048 & 28 & 2,123 & 28 & 2,187 & 28 & 2,253 & 28 \\
\hline $\begin{array}{l}\text { Process \& Industrial } \\
\text { Instrumentation }\end{array}$ & 1,317 & 18 & 1,382 & 18 & 1,423 & 18 & 1,466 & 18 \\
\hline Total $(\$ \times 100)$ & 9,071 & 124 & 9,779 & 124 & 10,072 & 124 & 10,375 & 124 \\
\hline
\end{tabular}




\section{LONG-RANGE WORK PLAN}

Long-range work projections by TSS are based on projections and funding levels of ORNL research divisions. 


\section{INTERNAL DISTRIBUTION}

1. B. P. Adkisson

2. G. T. Alley

3. K. L. Allison

4. M. E. Boren

5. B. C. Davis

6. R. P. Effler

7. H. C. Ford

8. R. G. Gilliland

9. J. L. Hammontree

10-14. R. A. Hess

15. G. D. Inman

16. J. M. Jansen

17. T. A. Keeble

18. D. N. Keller
19. D. W. McDonald

20. G. N. Miller

21. S. M. Odom

22. J. E. Payne

23. D. G. Prater

24. D. R. Smelcer

25. B. K. Swail

26. J. H. Swanks

27. J. D. White

28. Central Research Library

29. Laboratory Records (record copy)

30-31. Laboratory Records (OSTI)

32. I\&C Division Publications Office

\section{EXTERNAL DISTRIBUTION}

33. Edward Cumesty, ORNL Site Manager, DOE-ORO, P.O. Box 2008, 4500N, MS 6269, Oak Ridge, TN 37831-6269

34. Michele G. Branton, ORNL Maintenance Program Manager, DOE-ORO, P.O. Box 2008, 4500N, MS 6269, Oak Ridge, TN 37831-6269

35-39. D. C. Queen, DOE-ORO, P.O. Box 2009, 9114, MS 6269, Oak Ridge, TN 37831-6269

40. Ron Moore, The RM Group, Inc., 12024 Broadwood Drive, Knoxville, TN 37922

41. David Norton, Houston Advanced Research Center, 4800 Research Forest Dr., The Woodlands, TX 77381

42. M. M. Sevik, Caderock Division, Naval Surface Warfare Center, Code 70, Bethesda, MD 20084-5000

43. Ernesto Suarez, Pratt \& Whitney, P.O. Box 109600, MS 617-87, W. Palm Beach, FL 33410-9600 